Primljen / Received: 4.4.2017. Ispravljen / Corrected: 11.7.2017.

Prihvaćen / Accepted: 14.8.2017.

Dostupno online / Available online: 10.11.2017.

\section{Application of recycled steel fibres in concrete elements subjected to fatigue loading}

Authors:

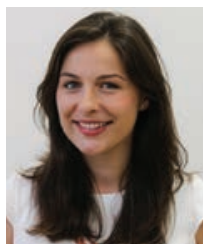

Marina Frančić Smrkić, MCE

University of Zagreb

Faculty of Civil Engineering

Department of Engineering Mechanics

mfrancic@grad.hr

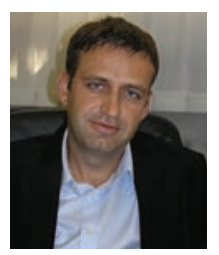

Assoc.Prof. Domagoj Damjanović, PhD. CE University of Zagreb

Faculty of Civil Engineering

Department of Engineering Mechanics ddomagoj@grad.hr

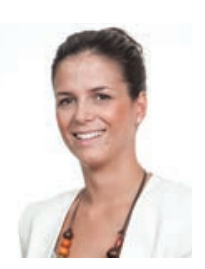

Assist.Prof. Ana Baričević, PhD. CE University of Zagreb

Faculty of Civil Engineering

Department of Engineering Materials abaricevic@grad.hr

\section{Marina Frančić Smrkić, Domagoj Damjanović, Ana Baričević}

\section{Application of recycled steel fibres in concrete elements subjected to fatigue loading}

Properties of concrete elements under fatigue load can be enhanced by adding steel fibres to the concrete mixture. An experimental study of recycled steel fibre reinforced concrete elements subjected to cyclic load is described. Fatigue design models are presented according to the fib Model Code 2010, ACI 215, and JSCE guidance. Design model calculations are compared to the results of experimental analyses. It can be observed that, as a rule, all design models underestimate the experimentally obtained fatigue resistance of concrete elements. The adjustment of the fib Model Code design model is proposed.

Key words:

fatigue, fibre reinforced concrete, experimental analysis, steel fibres, design model

Prethodno priopćenje

Marina Frančić Smrkić, Domagoj Damjanović, Ana Baričević

Primjena recikliranih čeličnih vlakana u betonskim elementima izloženima zamoru

Dodavanjem čeličnih vlakana u beton poboljšavaju se njegova svojstva pri zamoru. Opisana su eksperimentalna istraživanja betonskih elemenata s recikliranim čeličnim vlaknima pri cikličkom opterećenju. Prikazani su proračunski modeli zamora prema fib Model Code 2010, ACI 215 i JSCE smjernicama. Rezultati proračunskih modela uspoređeni su s rezultatima eksperimentalnog istraživanja. Uočeno je da, u pravilu, svi proračunski modeli podcjenjuju eksperimentalno određenu otpornost betona pri zamoru. Dan je prijedlog korekcije fib Model Code modela.

Ključne riječi:

zamor, mikroarmirani beton, eksperimentalno istraživanje, čelična vlakna, proračunski model

Vorherige Mitteilung

Marina Frančić Smrkić, Domagoj Damjanović, Ana Baričević

\section{Verwendung von recycelten Stahlfasern in Betonelementen unter Ermüdungsbeanspruchung}

Durch Zugabe von Stahlfasern werden die Eigenschaften von Beton unter Ermüdungsbeanspruchung verbessert. In der Arbeit werden experimentelle Untersuchungen von Betonelementen mit recycelten Stahlfasern bei zyklischen Ermüdungsbeanspruchungen beschrieben. Es werden Bemessungsmodelle nach dem fib Model Code 2010, ACl 215 und den JSCE-Richtlinien dargestellt. Die Ergebnisse der Bemessungsmodelle wurden mit den Ergebnissen der experimentellen Untersuchungen verglichen. Dabei konnte festgestellt werden, dass die Bemessungsmodelle die experimentell festgelegte Ermüdungsbeständigkeit von Beton in der Regel unterschätzen. In der Arbeit wird ein Vorschlag für die Korrektur des Modells fib Model Code gegeben.

Schlüsselwörter:

Ermüdung, mikroarmierter Beton, experimentelle Untersuchung, Stahlfasern, Bemessungsmodell 


\section{Introduction}

Fatigue is a phenomenon in which material subjected to cyclic loading can be damaged under the stress that is lower than its nominal static strength [1]. It can also be defined as a process of progressive, permanent internal structural changes in a material subjected to repeated loading [2]. In concrete, these changes are mainly associated with the progressive growth of internal microcracks. During repeated loading, microcracks grow and form macrocracks, which causes changes in mechanical properties of materials and degradation of stiffness. Due to their ability to control crack propagation, steel fibres have a positive effect on the performance of elements and structures subjected to repeated loading (pavements, bridge slab decks, railway sleepers, machinery foundations). From the engineering perspective, it is important to take fatigue into consideration in the assessment of the existing structures and also in the design of new structures and elements subjected to large number of repeated loadings. In recent times, the fatigue phenomenon has become a topical issue, especially in the design of bridge slab decks, which is mainly due to increasingly stringent technical requirements (higher speed, axle load, traffic frequency). Wider application of steel fibres is limited to a small number of structures, mostly because of high cost. Therefore, a considerable research effort is currently undertaken to find alternative types of fibres.

The research on the use of recycled steel fibres has been initiated some two decades ago at the University of Sheffiled [3-7] and it has been conducted over the last decade at the Faculty of Civil Engineering, University of Zagreb [8-13]. These studies have been mainly focusing on mechanical properties (compressive, tensile and flexural strength) of the recycled steel fibre reinforced concrete (RSFRC), and involved several cases of practical application of this material. The use of recycled steel fibres as reinforcement in concrete pavements was analysed in [7]. The effect of cyclic loading, i.e. fatigue, was studied on prisms reinforced with fibres and the results were promising due to positive influence of fibres during the loading procedure. Previous research efforts have revealed that, due to their mechanical properties, recycled fibres can not entirely replace manufactured fibres, but can efficiently replace a certain amount of these fibres $[14,15]$. Thus the idea of combining recycled and manufactured fibres was initiated, which resulted in development of the hybrid recycled steel fibre concrete (HSFRC).

The HSFRC has a great potential for improving fatigue life as recycled fibres, due to their shorter length, prevent propagation of microcracks, while manufactured fibres prevent propagation of macrocracks. Such a combination of fibres could provide a beneficial synergic effect, along with economical savings, while at the same time being an appropriate environmental solution to the waste tyres disposal problem. This hypothesis has partly been confirmed by a number of experiments focusing on the influence of recycled and manufactured fibres in concrete [7]. These experiments have revealed that the two types of fibres are activated at different crack width stages. The aim of this paper is to assess behaviour of HSFRC under fatigue.

\section{Materials and testing methods}

\subsection{Materials}

The mix design is shown in Table 1. Each mix has an ID which denotes the proportion of manufactured and recycled steel fibres in kg per cubic meter of concrete. Mix 20M20R contains $20 \mathrm{~kg}$ of manufactured fibres and $20 \mathrm{~kg}$ of recycled fibres per cubic meter of concrete, while mix $40 \mathrm{MOR}$ contains $40 \mathrm{~kg}$ of manufactured and $0 \mathrm{~kg}$ of recycled fibres per cubic meter of concrete. Mix PC is composed of plain concrete.

Table 1. Mix design

\begin{tabular}{|l|c|c|c|}
\hline \multicolumn{1}{|r|}{ Mix } & PC & 40M0R & 20M20R \\
\hline Components $\left[\mathrm{kg} / \mathrm{m}^{3}\right]$ & \multicolumn{3}{|c|}{370} \\
\hline Cement & \multicolumn{3}{|c|}{170} \\
\hline Water & \multicolumn{3}{|c|}{0.46} \\
\hline W/c ratio & & 2.22 & 20 \\
\hline Superplasticiser & 0 & 40 & 20 \\
\hline Manufactured steel fibres & 0 & 0 & 1825 \\
\hline Recycled steel fibres & 1840 & 1825 & \\
\hline Aggregate (all sizes) & \multicolumn{3}{|c|}{20} \\
\hline
\end{tabular}

The concrete consisted of river aggregate passing through the sieve of $0 / 4 \mathrm{~mm}$ (crushed), 4/8 $\mathrm{mm}$ and 8/16 $\mathrm{mm}$, and cement type CEM II/A-M (S-V) $42.5 \mathrm{~N}$. Grading curves for aggregate are shown in Figure 1.

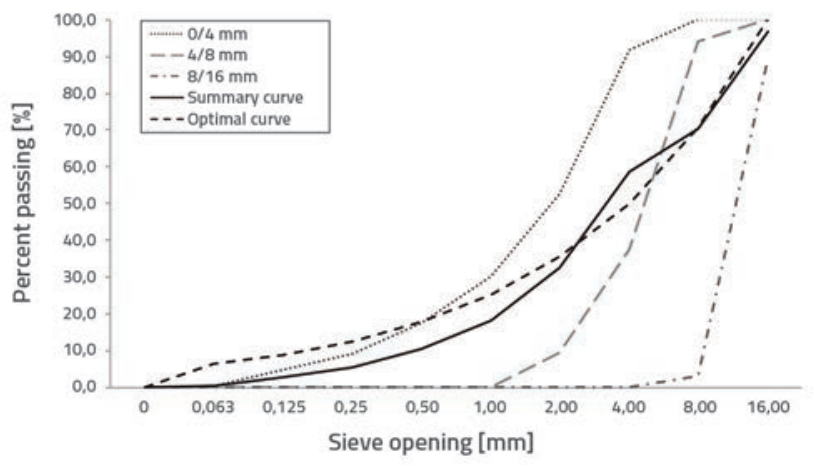

Figure 1. Aggregate grading curves

The polycarboxylic ether superplasticiser with long lateral chains was used to achieve the class $\mathrm{S} 4$ concrete workability (slump $160 \mathrm{~mm}-210 \mathrm{~mm}$ ). Manufactured steel fibres used in 
Table 2. Geometrical and mechanical properties of fibres [17]

\begin{tabular}{|c|c|c|c|c|c|}
\hline Fibre type & $\begin{array}{c}\text { Length } \\
{[\mathrm{mm}]}\end{array}$ & $\begin{array}{c}\text { Diameter } \\
{[\mathrm{mm}]}\end{array}$ & $\begin{array}{c}\text { Aspect ratio } \\
(\mathrm{I} / \mathrm{d})\end{array}$ & $\begin{array}{c}\text { Tensile strength } \\
{\left[\mathrm{N} / \mathrm{mm}^{2}\right]}\end{array}$ & Tensile strength \\
\hline Manufactured fibres & 35 & 0.55 & 64 & 1100 & Zavinuti krajevi \\
\hline Recycled fibres & $20 \pm 2$ & $0.15 \pm 0.04$ & 133 & 2850 & Valovit \\
\hline
\end{tabular}

Table 3. Testing methods for fresh and hardened concrete properties

\begin{tabular}{|c|c|c|}
\hline Property & Standard & Dimensions [mm] \\
\hline Density & HRN EN 12350-6 [18] & - \\
\hline Air content & HRN EN 12350-7 [19] & - \\
\hline Consistency-slump test & HRN EN 12350-2 [20] & $150 \times 150 \times 150$ \\
\hline Compressive strength & HRN EN 12390-3 [21] & $\Phi / /=150 / 300$ \\
\hline Splitting tensile strength & HRN EN 12390-6 [22] & $\Phi / /=150 / 300$ \\
\hline Modulus of elasticity & HRN EN 12390-13 [23] & $150 \times 150 \times 600$ \\
\hline Flexural tensile strength & HRN EN 14651 [24] & \\
\hline
\end{tabular}

this research are straight fibres with hooked ends, $35 \mathrm{~mm}$ in length and $0.55 \mathrm{~mm}$ in diameter. Recycled fibres are irregular in shape and size, due to the mechanical recycling process. Average geometrical and mechanical properties of both types of fibres are shown in Table 2 and Figure 2.

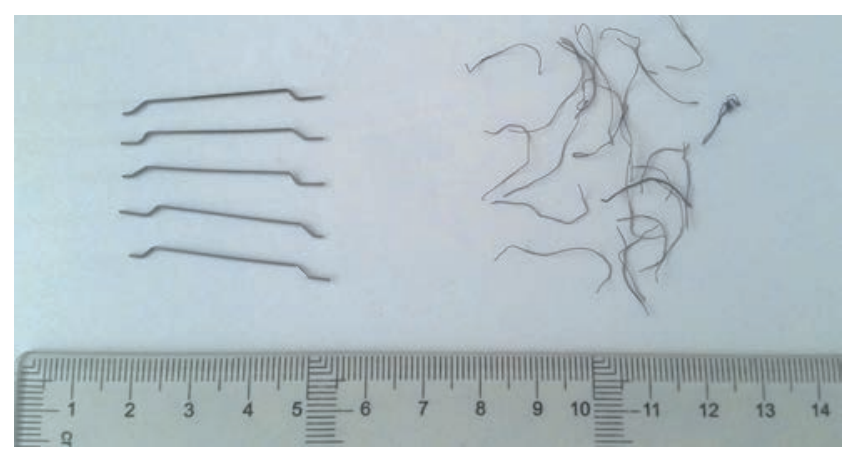

Figure 2. Comparison of manufactured and recycled fibres
The variability of recycled fibres is determined using the optical correlation technique developed at company Twincon Ltd, Sheffield [16]. The recycled fibres measure on an average $20 \mathrm{~mm}$ in length and $0.15 \mathrm{~mm}$ in diameter, while their tensile strength is higher when compared to manufactured fibres.

\subsection{Testing methods}

Fresh and hardened concrete properties were determined according to European standards, Table 3. Non standardised test methods are also explained.

Flexural tensile strength was determined on notched prism specimens. The notch was made at midspan of the specimens (5 mm wide and $25 \mathrm{~mm}$ deep). The HSFRC specimens were tested according to HRN EN 14651 [24]. The same procedure was used for plain concrete specimens,
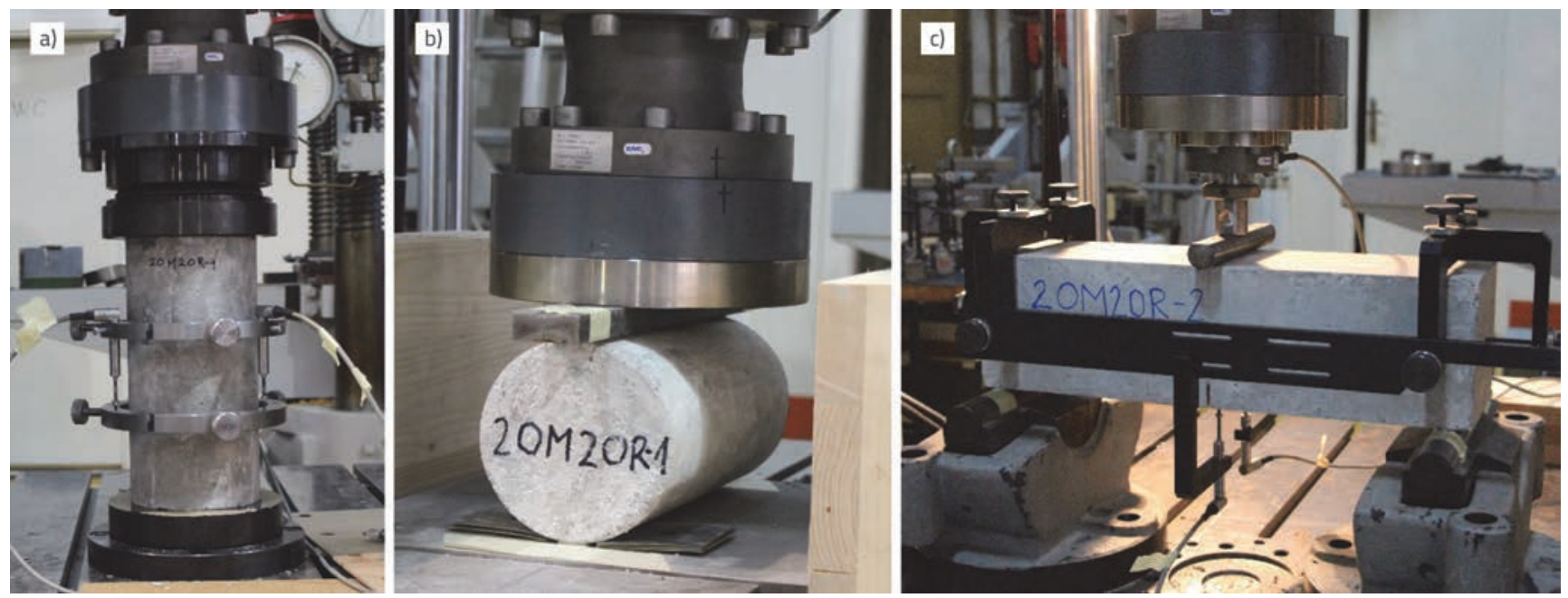

Figure 3. Test setup: a) modulus of elasticity, b) splitting tensile strength, c) flexural tensile strength 
but with the ten times lower loading rate, in order to prevent sudden failure of specimens. The span length for the three point bending test was $500 \mathrm{~mm}$. The standard prescribes CMOD (Crack Mouth Opening Displacement) measurement during the test but also allows displacement measurement and subsequent calculation of CMOD via displacement values. Two LVDT (Linear Variable Differential Transformer) sensors for vertical displacement measurement were used, one on each side of the specimen, and the result is shown as an average value. Three specimens were tested for each mix.

\subsection{Test setup}

As there is no standard procedure for carrying out fatigue tests on concrete, guidelines from the ACl Committee 544 Measurement of Properties of Fiber Reinforced Concrete - were taken into consideration during preparation of the test setup [25], as well as the testing setup guidelines proposed by other researchers [26].

Fatigue tests are usually time consuming and expensive as they can extend over as many as ten million cycles. To optimise testing time, a special frame enabling simultaneous fatigue testing for three prisms $(150 \mathrm{~mm} \times 150 \mathrm{~mm} \times 600$ $\mathrm{mm}$ ) was manufactured, as shown in Figure 4. Yokes were placed at mid-height of each specimen and LVDTs were mounted on them to measure vertical displacements. A static flexural test was conducted prior to fatigue tests to define the LOP (Limit of Proportionality) static load. For each mix, the load obtained from the static test was multiplied by 4 different stress levels $S$ to calculate the load for the fatigue test. During the test, a minimum of $10 \%$ of the load was continuously applied to the specimens whilst the maximum load was at $30 \%, 50 \%, 70 \%$ and $90 \%$ of the static load. The load was applied based on a sinusoidal wave pattern, at a frequency of $15 \mathrm{~Hz}$ until any of the three specimens failed or reached 2 million cycles. The fatigue loading was applied by a $250 \mathrm{kN}$ hydraulic actuator. The actuator was set to stop when the displacement would exceed $10 \mathrm{~mm}$, i.e. at specimen failure. When one of the specimens failed, it was replaced by a dummy specimen that had the same dimensions as the original specimen, the only difference being that it was reinforced with steel rebars. Dummy specimens were used to ensure load transfer onto remaining specimens in the testing rig. The main parameter determined by experimental testing was the number of cycles until failure at each stress level. Additionally, a total of 6 LVDT sensors were used for vertical displacement measurement. Two LVDTs were used per specimen, one on each side, and deflection was determined as their average value. The frequency of data acquisition was $300 \mathrm{~Hz}$ in order to capture the sinusoidal wave pattern of displacements in each loading cycle, as shown in Figure 5.

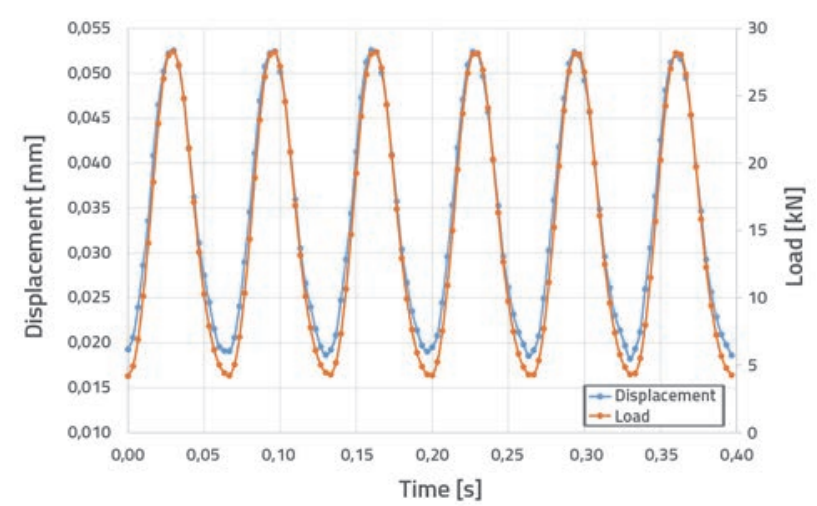

Figure 5. Sinusoidal wave pattern of displacements and loads

As mentioned earlier, there is no standard procedure for carrying out fatigue tests for concrete. The fatigue data obtained from a particular test setup can not be directly compared to the data obtained from a different loading configuration. Therefore, results are often presented

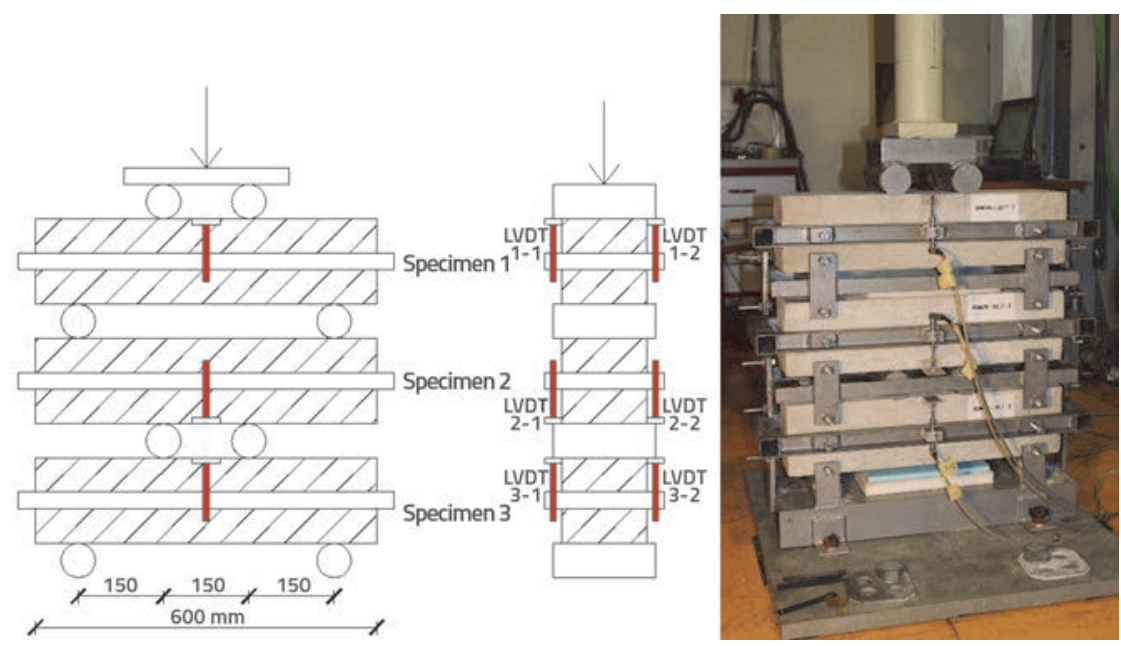

Figure 4. Fatigue test setup in a form of S-N curves, also known as Wöhler curves, representing the relation between the stress level and the number of cycles at the moment of failure. The dimensionless term S, which represents the ratio between maximum stress during a particular fatigue test and static strength at LOP, largely eliminates influences such as the specimen size and shape, concrete strength, moisture condition, curing condition, etc. Thus, dimensionless S-N curves describe most accurately the behaviour of concrete under fatigue [2]. The logarithmic scale S-logN is used in the majority of cases. 


\section{Results and discussion}

\subsection{Fresh concrete properties}

When added to fresh concrete, steel fibres interweave and form the so called "balls". This has a negative influence on the workability of fresh concrete [27-29]. Research undertaken so far has shown that an increase in fibre volume in concrete causes reduction in the workability of fresh concrete, as tested with slump method [30]. This was also confirmed in this study where slump test results were by $20 \%$ lower when both steel fibre types were added, compared to plain concrete mix. Despite workability reduction, all mixtures were categorized as 54 , Table 4.

Table 4. Fresh concrete properties

\begin{tabular}{|c|c|c|c|}
\hline Mix & $\begin{array}{c}\text { Slump } \\
{[\mathrm{mm}]}\end{array}$ & $\begin{array}{c}\text { Density } \\
{\left[\mathrm{kg} / \mathrm{m}^{3}\right]}\end{array}$ & $\begin{array}{c}\text { Air content } \\
{[\%]}\end{array}$ \\
\hline PC & 200 & 2368 & 1.4 \\
\hline $20 \mathrm{M} 20 \mathrm{R}$ & 160 & 2332 & 2.8 \\
\hline 40MOR & 160 & 2366 & 3.1 \\
\hline
\end{tabular}

The air content increase is associated with the addition of fibres, mixing procedure, and fibre volume [3, 31]. Although recycled fibres have the tendency to bungle more than manufactured fibres, and therefore the addition of recycled fibres could have a greater effect on the workability and air content compared to manufactured fibres, this was not observed during testing. The difference in air content between two fibre mixes was $10 \%$, while similar results were obtained by slump test. Due to small fibre volume in concrete mixes (< $0.5 \%$ of total volume), the addition of fibres did not affect the density of concrete, Table 4.

\subsection{Hardened concrete properties}

The compressive strength, modulus of elasticity, and splitting tensile strength values of all mixtures are presented in Table 5. The average value and standard deviation were determined based on results obtained on three specimens tested for each mix.

Usually, the compressive strength slightly decreases when recycled steel fibres are added to concrete [30, 32]. This research confirmed that the addition of fibres causes decrease in compressive strength, Table 5 . This decrease is in correlation with air content increase, which is a direct consequence of the addition of fibres to concrete. For PC mix with an air content of $1.4 \%$ (mix PC), the compressive strength was $48.1 \pm 0.9 \mathrm{MPa}$, while the compressive strength was $42.5 \pm 0.3 \mathrm{MPa}$ for $20 \mathrm{M} 20 \mathrm{R}$ mix containing $2.8 \%$ of air.

A similar trend was also noted for the modulus of elasticity, which is in accordance with the literature [31] showing that the addition of fibres does not greatly affect the modulus of elasticity of concrete. For mixtures 20M20R and 40M0R, the modulus of elasticity reduced by $7 \%$ and $9 \%$ compared to plain concrete. The tensile splitting strength increased by $45 \%$ and $32 \%$ for concrete mixtures with fibre, compared to plain concrete.

Table 5. Compressive strength, modulus of elasticity, and splitting tensile strength

\begin{tabular}{|c|c|c|c|}
\hline Mix & $\begin{array}{c}\text { Compressive } \\
\text { strength } \pm \mathbf{~ s} \\
{[\mathrm{MPa}]}\end{array}$ & $\begin{array}{c}\text { Modulus of } \\
\text { elasticity } \pm \mathbf{s} \\
{[\mathrm{GPa}]}\end{array}$ & $\begin{array}{c}\text { Splitting tensile } \\
\text { strength } \pm \mathbf{~ s} \\
{[\mathrm{MPa}]}\end{array}$ \\
\hline PC & $48.1 \pm 0.9$ & $32.9 \pm 1.1$ & $3.1 \pm 0.2$ \\
\hline 20M20R & $42.5 \pm 0.3$ & $30.6 \pm 0.8$ & $4.5 \pm 0.3$ \\
\hline $40 \mathrm{MOR}$ & $46.8 \pm 0.7$ & $30.1 \pm 0.7$ & $4.1 \pm 0.1$ \\
\hline
\end{tabular}

Fibres in concrete slow down the propagation of cracks, which in turn increases toughness of this otherwise brittle material. The fibre that stands in the way of crack propagation bridges the gap and resists further progression of a crack, through energy dissipation caused by fibre pullout. Flexural test results for prism specimens are shown in form of load-displacement curves, Figures 6-8. Previous research has shown that there is a synergy between the manufactured and recycled fibres [13], where synergy implies enhanced ductility of hybrid concrete when compared to the ductility of concrete with one type of fibres only. With an optimum volume content of two fibre types, it is possible to design HSFRC with properties that are similar or equal to those of the reference SFRC. The limit of proportionality $\left(\mathrm{f}_{\mathrm{ct,L}}\right)$ and residual flexural strength values are shown in Table 6 for four characteristic points $\left(f_{R, 1}-f_{R, 4}\right)$. Residual flexural strength values $f_{r, 1}$ and $f_{r, 3}$ are considered to be parameters which describe behaviour of SFRC at the ultimate limit state (ULS) and the serviceability limit state (SLS) [33]. Residual flexural strength $\mathrm{f}_{\mathrm{R}, 1}$ of mixtures $20 \mathrm{M} 20 \mathrm{R}$ and $40 \mathrm{MOR}$ increased several times when compared to the reference $P C$ mix. At the residual flexural strength of $f_{r, 3^{\prime}}$ the plain concrete is no longer able to withstand the load, while both fibre mixtures still demonstrate a high bearing capacity. The hybrid mix 20M20R shows the value of $f_{r, 3}$ that is by no more than $18 \%$ lower when compared to mix $40 M 0 R$. This slightly lower value is a consequence of a smaller volume share of longer and thicker fibres, which ensure ductility at larger crack widths. 


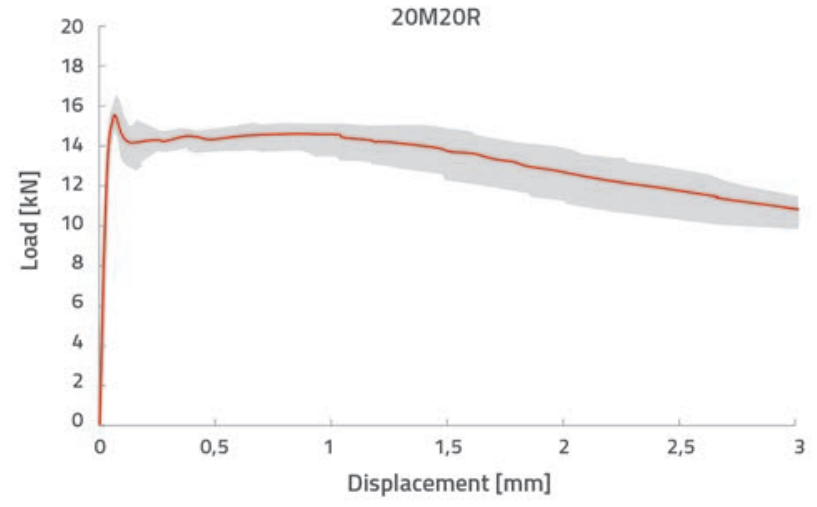

Figure 6. Load-displacement diagram with scatter for mix 20M20R

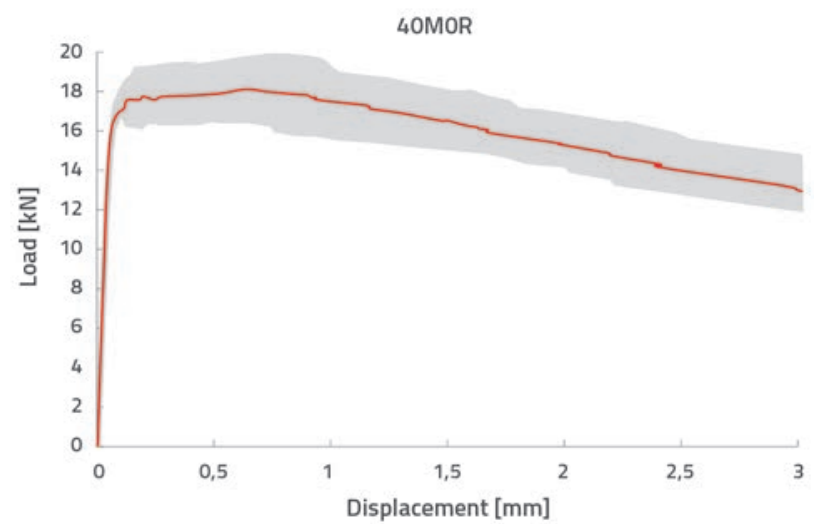

Figure 7. Load-displacement diagram with scatter for mix 40MOR

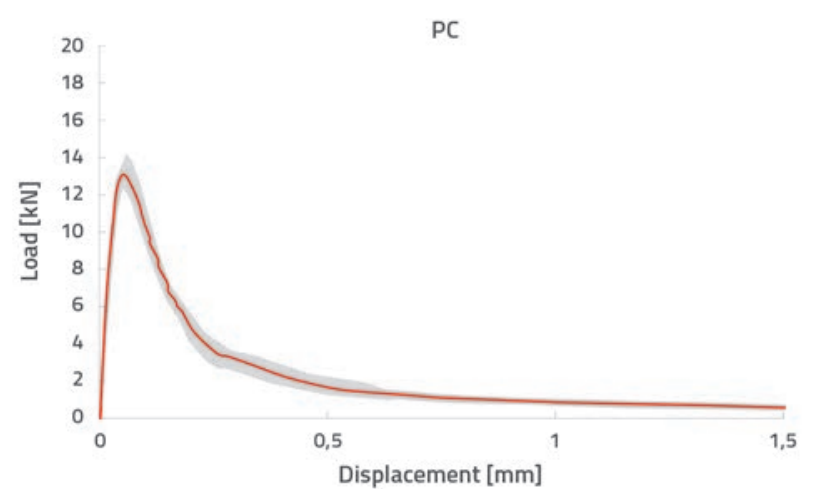

Figure 8. Load-displacement diagram with scatter for PC mix

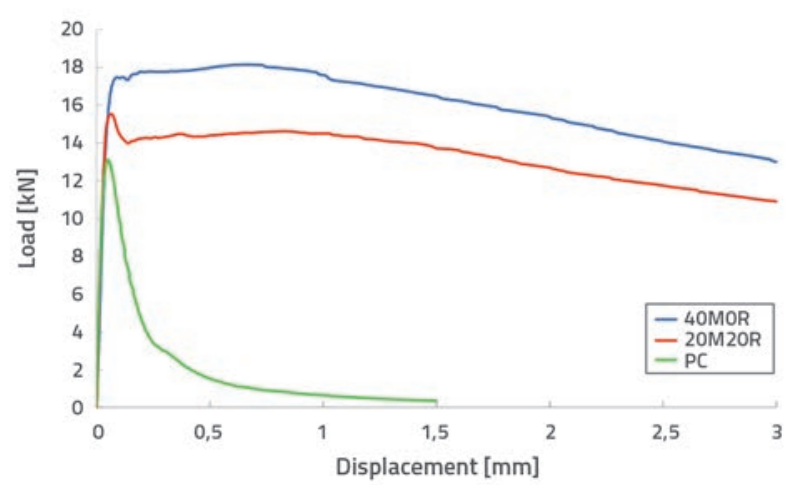

Figure 9. Load-displacement diagram for all mixes

Table 6. Flexural strengths at LOP and at four characteristic points

\begin{tabular}{|c|c|c|c|c|c|}
\hline Flexural strength & $\begin{array}{c}\boldsymbol{f}_{\mathrm{ct.l}} \\
{[\mathrm{MPa}]}\end{array}$ & $\begin{array}{c}\boldsymbol{f}_{\mathrm{R} .1} \\
{[\mathrm{MPa}]}\end{array}$ & $\begin{array}{c}\mathbf{f}_{\mathrm{R} .2} \\
{[\mathrm{MPa}]}\end{array}$ & $\begin{array}{c}\boldsymbol{f}_{\mathrm{R} .3} \\
{[\mathrm{MPa}]}\end{array}$ & $\begin{array}{c}\boldsymbol{f}_{\mathrm{R} .4} \\
{[\mathrm{MPa}]}\end{array}$ \\
\hline PC & $4.25 \pm 0.29$ & $0.56 \pm 0.15$ & $0.15 \pm 0.05$ & 0 & 0 \\
\hline $20 \mathrm{M} 20 \mathrm{R}$ & $5.00 \pm 0.21$ & $4.59 \pm 0.13$ & $4.50 \pm 0.28$ & $3.94 \pm 0.35$ & $3.46 \pm 0.23$ \\
\hline $40 \mathrm{MOR}$ & $5.57 \pm 0.16$ & $5.74 \pm 0.39$ & $5.39 \pm 0.42$ & $4.78 \pm 0.38$ & $4.16 \pm 0.39$ \\
\hline
\end{tabular}

Table 7. Load and stress values obtained by static and fatigue test

\begin{tabular}{|c|c|c|c|c|c|c|c|}
\hline \multicolumn{4}{|c|}{ STATIC TEST } & \multicolumn{4}{|c|}{ FATIGUE TEST } \\
\hline Specimen ID & $\begin{array}{l}\text { Load } \\
{[\mathrm{kN}]}\end{array}$ & $\begin{array}{l}\text { Average load } \\
{[\mathrm{kN}]}\end{array}$ & $\begin{array}{c}\text { Static strength } \\
{[\mathrm{MPa}]}\end{array}$ & Stress level S & $\begin{array}{l}\text { Max. load } \\
{[\mathrm{kN}]}\end{array}$ & $\begin{array}{l}\text { Max. stress } \\
{[\mathrm{MPa}]}\end{array}$ & $\begin{array}{l}\text { No. of tested } \\
\text { specimens }\end{array}$ \\
\hline $\begin{array}{l}\text { PC-S1 } \\
\text { PC-S2 } \\
\text { PC-S3 }\end{array}$ & $\begin{array}{l}33.8 \\
33.1 \\
32.2\end{array}$ & $33.0 \pm 0.6$ & 4.4 & $\begin{array}{l}0.3 \\
0.5 \\
0.7 \\
0.9\end{array}$ & $\begin{array}{c}9.9 \\
16.5 \\
23.1 \\
29.7\end{array}$ & $\begin{array}{l}1.32 \\
2.20 \\
3.08 \\
3.96\end{array}$ & $\begin{array}{l}2 \\
3 \\
3 \\
3\end{array}$ \\
\hline $\begin{array}{l}\text { 20M20R-S1 } \\
\text { 20M20R S2 } \\
\text { 20M20R-S3 }\end{array}$ & $\begin{array}{l}40.9 \\
42.4 \\
38.1\end{array}$ & $40.5 \pm 1.8$ & 5.4 & $\begin{array}{l}0.3 \\
0.5 \\
0.7 \\
0.9\end{array}$ & $\begin{array}{l}12.2 \\
20.3 \\
28.4 \\
36.5\end{array}$ & $\begin{array}{l}1.62 \\
2.70 \\
3.78 \\
4.86\end{array}$ & $\begin{array}{l}3 \\
3 \\
3 \\
2\end{array}$ \\
\hline $\begin{array}{l}\text { 40MOR-S1 } \\
\text { 40MOR-S2 } \\
\text { 40MOR-S3 }\end{array}$ & $\begin{array}{l}41.7 \\
39.3 \\
39.2\end{array}$ & $40.1 \pm 1.2$ & 5.4 & $\begin{array}{l}0.3 \\
0.5 \\
0.7 \\
0.9\end{array}$ & $\begin{array}{l}12.0 \\
20.1 \\
28.1 \\
36.1\end{array}$ & $\begin{array}{l}1.62 \\
2.70 \\
3.78 \\
4.86\end{array}$ & $\begin{array}{l}2 \\
3 \\
3 \\
3\end{array}$ \\
\hline
\end{tabular}




\subsection{Fatigue test results}

The static flexural test was conducted prior to fatigue test to define the limit of proportionality static load on three specimens for each mix. This was a four-point loading test at a span of 450 $\mathrm{mm}$, the same as for the fatigue test setup, Figure 4 . The results are shown in Table 7, together with the calculated maximum stress values at four different stress levels.

All tested specimens reached two million cycles of loading at lower stress levels ( $\mathrm{S}=0.3$ and $\mathrm{S}=0.5$ ). Results obtained at higher stress

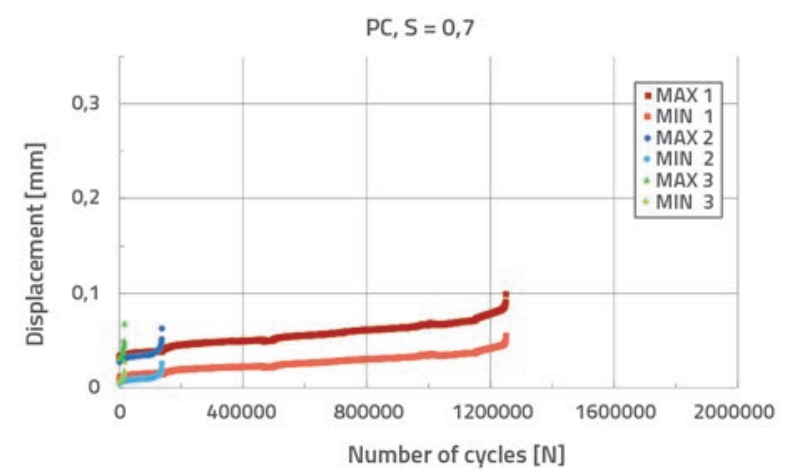

Figure 10. Displacement-number of cycles diagram for PC mix at stress level $\mathbf{S}=0.7$

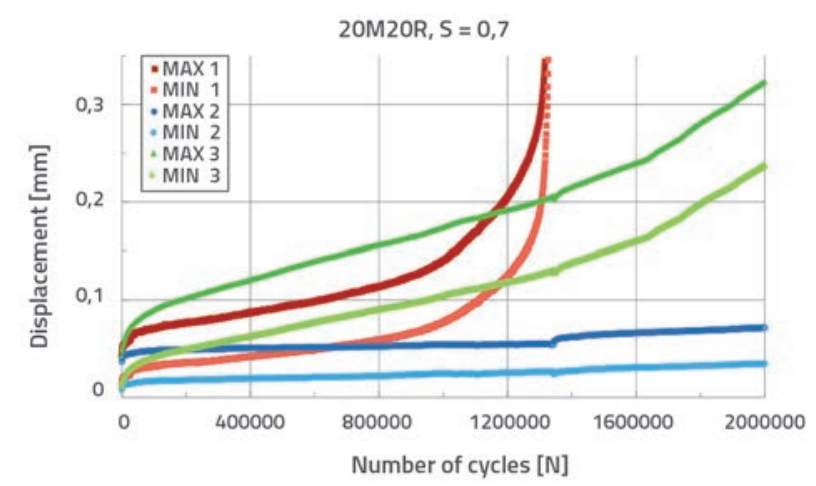

Figure 12. Displacement-number of cycles diagram for 20M20R mix at stress level $\mathrm{S}=0.7$

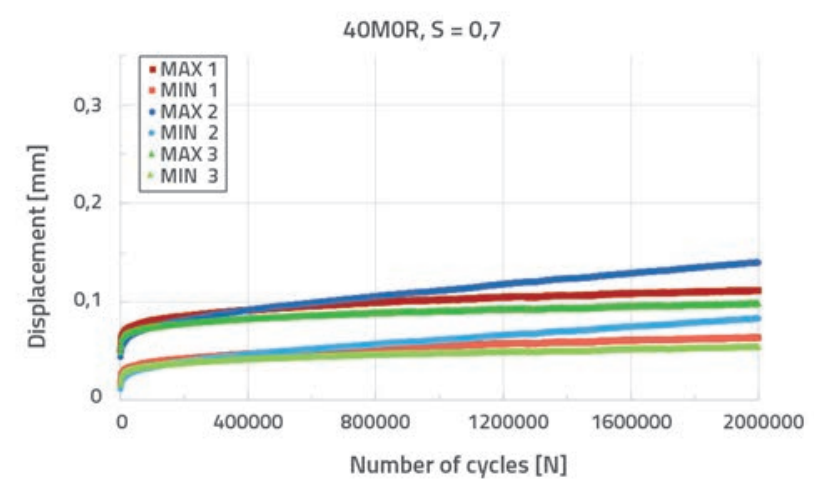

Figure 14. Displacement-number of cycles diagram for 40MOR mix at stress level $\mathbf{S}=0.7$ levels ( $\mathrm{S}=0.7$ and $\mathrm{S}=0.9$ ) are shown in the form of maximum and minimum displacements vs. number of cycles diagrams, Figures 10 to 15 . Some scatter of results can be observed, which is common for concrete [2] due to inhomogeneity of material, or because specimens tested for fatigue are not the same as the one on which static strength was determined. Furthermore, the variability of results is more pronounced in fibre mixtures due to random distribution of fibres in the matrix.

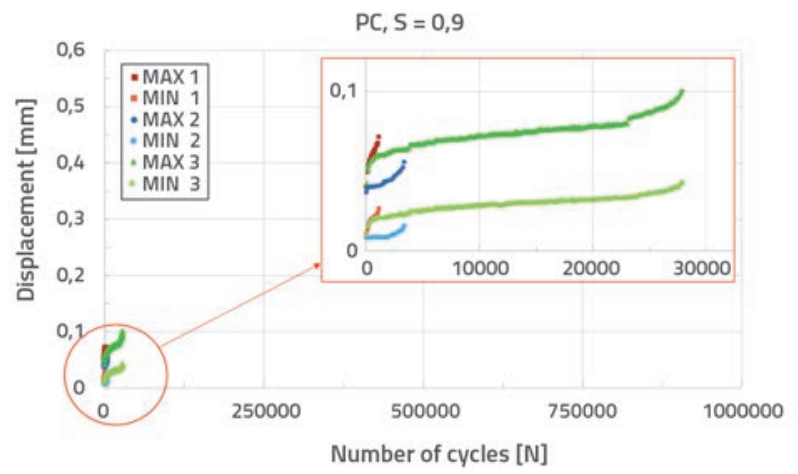

Figure 11. Displacement-number of cycles diagram for PC mix at stress level $\mathrm{S}=0.9$

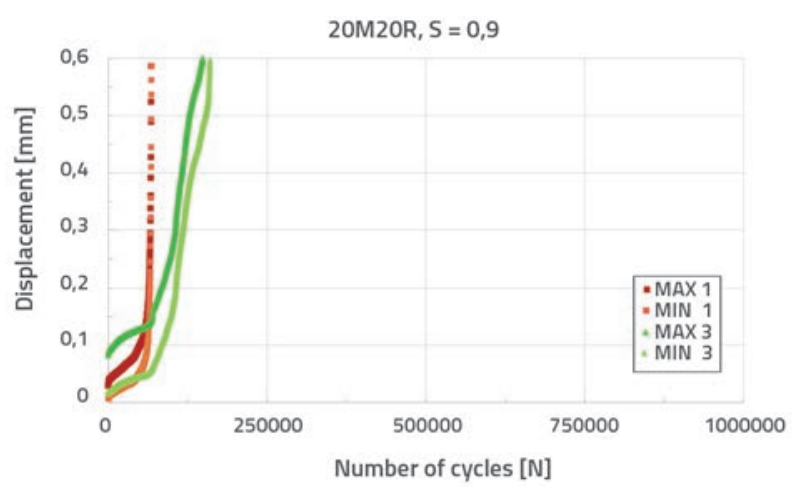

Figure 13. Displacement-number of cycles diagram for 20M20R mix at stress level $\mathrm{S}=0.9$

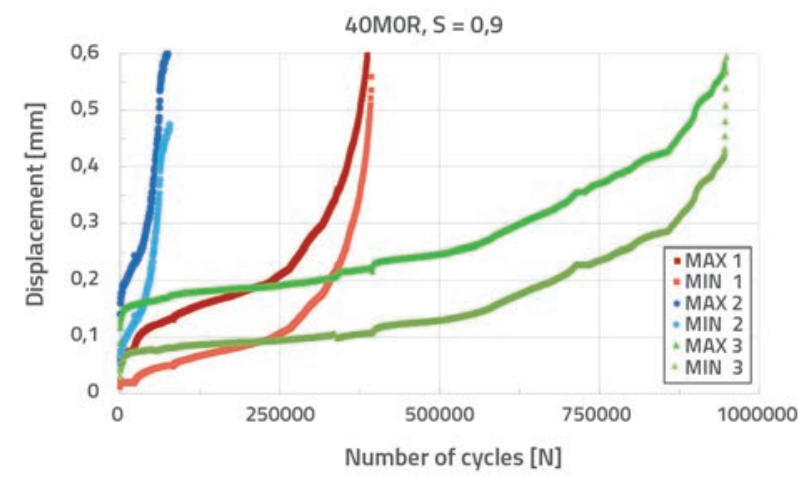

Figure 15. Displacement-number of cycles diagram for 40MOR mix at stress level $\mathbf{S}=0.9$ 
Table 8. Number of cycles for each specimen

\begin{tabular}{|c|c|c|c|c|c|c|c|c|}
\hline \multirow{2}{*}{$\begin{array}{c}\text { Test } \\
\text { samples }\end{array}$} & \multicolumn{2}{|c|}{$S=0.3$} & \multicolumn{2}{|c|}{$S=0.5$} & \multicolumn{2}{|c|}{$S=0.7$} & \multicolumn{2}{|c|}{$S=0.9$} \\
\hline & $\mathbf{N}$ & $\log N$ & $\mathbf{N}$ & $\log N$ & N & $\log N$ & N & $\log N$ \\
\hline PC & $\begin{array}{l}2.000 .000 \\
2.000 .000\end{array}$ & $\begin{array}{l}6.30 \\
6.30\end{array}$ & $\begin{array}{l}2.000 .000 \\
2.000 .000 \\
2.000 .000\end{array}$ & $\begin{array}{l}6.30 \\
6.30 \\
6.30\end{array}$ & $\begin{array}{c}1.250 .500 \\
137.670 \\
16.990\end{array}$ & $\begin{array}{l}6.10 \\
5.14 \\
4.23\end{array}$ & $\begin{array}{c}1170 \\
3380 \\
27.900\end{array}$ & $\begin{array}{l}3.07 \\
3.53 \\
4.45\end{array}$ \\
\hline 20M20R & $\begin{array}{l}2.000 .000 \\
2.000 .000 \\
2.000 .000\end{array}$ & $\begin{array}{l}6.30 \\
6.30 \\
6.30\end{array}$ & $\begin{array}{l}2.000 .000 \\
2.000 .000 \\
2.000 .000\end{array}$ & $\begin{array}{l}6.30 \\
6.30 \\
6.30\end{array}$ & $\begin{array}{l}1.342 .700 \\
2.000 .000 \\
2.000 .000\end{array}$ & $\begin{array}{l}6.13 \\
6.30 \\
6.30\end{array}$ & $\begin{array}{c}70.170 \\
167.500\end{array}$ & $\begin{array}{l}4.85 \\
5.22\end{array}$ \\
\hline 40MOR & $\begin{array}{l}2.000 .000 \\
2.000 .000\end{array}$ & $\begin{array}{l}6.30 \\
6.30\end{array}$ & $\begin{array}{l}2.000 .000 \\
2.000 .000 \\
2.000 .000\end{array}$ & $\begin{array}{l}6.30 \\
6.30 \\
6.30\end{array}$ & $\begin{array}{l}2.000 .000 \\
2.000 .000 \\
2.000 .000\end{array}$ & $\begin{array}{l}6.30 \\
6.30 \\
6.30\end{array}$ & $\begin{array}{c}394.050 \\
77.440 \\
975.600\end{array}$ & $\begin{array}{r}5.60 \\
4.89 \\
45.99\end{array}$ \\
\hline
\end{tabular}

Table 8 shows the number of cycles for each tested specimen. The $\mathrm{S}-\log \mathrm{N}$ chart is shown in Figure 16. The testing was stopped at two million cycles, which is a common practice for concrete fatigue testing $[2,7,34]$. Specimens that reached two million cycles at the end of the test are marked with arrows in Figure 16. The damage to these specimens was minor and they would have probably reached many more cycles if testing were to continue. While creating S-N curves, such specimens give a wrong idea about true behaviour of the material because their position in the chart is underrated, i.e. they should have been positioned at a higher value of $\operatorname{logN}$. Therefore, the specimens tested at stress levels $S=0.3$ and $S=0.5$ were excluded from further consideration, and $\mathrm{S}-\mathrm{N}$ curves were formed based on test data for stress levels $S=0.7$ and $S=0.9$.

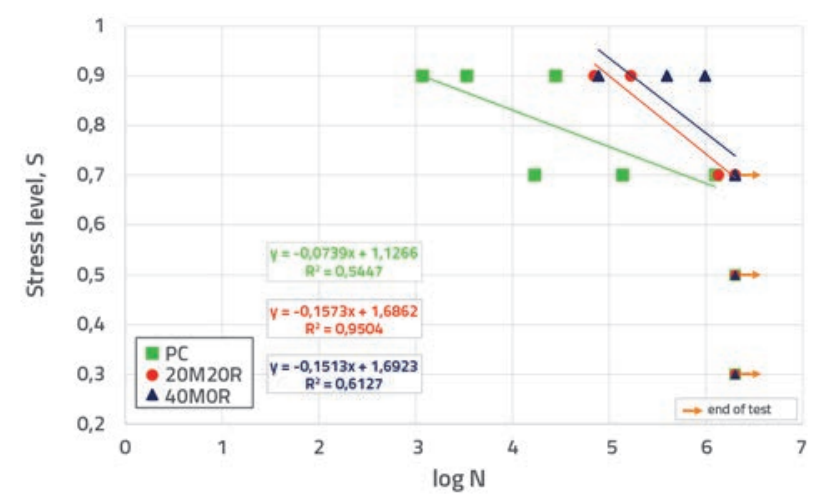

Figure 16. $S-\log N$ chart with related fatigue equations

The analysis of results obtained by the SFRC fatigue testing has shown that the contribution of recycled fibres can be improved by combining them with manufactured fibres. In fact, it was previously demonstrated that recycled fibres exposed to fatigue can postpone the connection of microcracks [26]. However, a sudden change in post-crack region occurs due to fast pull-out of fibres from cement matrix, and microcracks form quite rapidly. On the other hand, manufactured fibres control macrocracks development, while displacements are linearly increasing. This is why the contribution of recycled fibres can be enhanced by combining them with manufactured fibres. The idea of such design is similar to the aggregate grading, where different grain sizes are combined to achieve better concrete properties. The analysis of results presented in Figures 10 to 16 and in Table 8 has shown that a synergy exists between longer and thicker fibres (aspect ratio: 67), which ensure ductility at wider cracks, and shorter and thinner fibres (> $85 \% \mathrm{l}=0-15 \mathrm{~mm}, \Phi_{\text {mean }}=0.13 \mathrm{~mm}$ ). This ensures load transmission during the microcracking process and in the macrocracks development phase, when a considerable number of very fine and thin cracks are present. However, the faster progress of macrocracks is evident from the results for mix 20M20R presented in Figure 12 to 15, which is a response to the sudden increase in displacement values at lower number of cycles with reference to mix 40MOR.

\section{Fatigue design model}

The results of experimental study will be compared to theoretical fatigue design models for concrete, which are listed in design standards. These models were developed based on experimental tests which are not standardised, which points to the problems faced in this area. It is important to stress that all design models have been developed for the fatigue of plain concrete, and so the intention is to grade theirs potential applicability to SFRC and HSFRC.

Three design models will be used for comparison: fib Model Code 2010 [33] (marked hereafter MC), ACI (American Concrete Institute) Code 215 [35, 36] (marked hereafter ACI) and JSCE (Japan Society of Civil Engineers) standard [37] (marked hereafter JSCE). It is interesting to note that Eurocode 2 does not give guidance for fatigue of concrete under tension or flexure, i.e. the guidance is limited to pure compression and shear. That is why it will not be considered.

\section{1. fib Model Code 2010}

For constant stress amplitude, the number of cycles $N$ causing fatigue of plain concrete may be estimated from equations (1) to (11). They are valid for pure compression, compressiontension, and pure tension. 


\section{a) Pure compression}

For pure compression, the logarithmic value of the expected number of cycles can be determined from one of the two following equations:

$\log N_{1}=\frac{8}{(Y-1)}\left(S_{c, \max }-1\right)$

$\log N_{2}=8+\frac{8 \ln (10)}{(Y-1)}\left(Y-S_{c, \text { min }}\right) \cdot \log \left(\frac{S_{c, \text { max }}-S_{c, \text { min }}}{Y-S_{c, \text { min }}}\right)$

where:

if $\log N_{1} \leq 8$, then $\log N=\log N_{1}$

if $\log N_{1}>8$, then $\log N=\log N_{2}$

where parameter $Y$ is defined as

$Y=\frac{0,45+1,8 \cdot S_{c, \text { min }}}{1+1,8 \cdot S_{c, \text { min }}-0,3 \cdot S_{c, \text { min }}^{2}}$

In eq. (1), (2) and (5), $S_{c, \max }$ and $S_{c, \text { mim }}$ represent maximum and minimum compressive stress levels:

$S_{c, \max }=\frac{\left|\sigma_{c, \max }\right|}{f_{c k, f a t}}$

$S_{c, \min }=\frac{\left|\sigma_{c, \min }\right|}{f_{c k, f a t}}$

while $\sigma_{c, \max }$ and $\sigma_{c, \text { min }}$ are maximum and minimum compressive stress levels under fatigue, and $f_{c k, f a t}$ is the fatigue reference compressive strength defined as:

$f_{c k, f a t}=\beta_{c c}(t) \beta_{c, s u s}\left(t, t_{0}\right) f_{c k}\left(1-f_{c k} / 400\right)$

In eq. (8), $\beta_{c c}(t)$ is the coefficient that depends on the age of concrete at the beginning of fatigue load, and $\beta_{c, \text { sus }}\left(t, t_{0}\right)$ is the coefficient that takes into account the effect of high mean stress during load, and can be adopted as $\beta_{\mathrm{c}, \text { sus }}\left(t, t_{0}\right)=0,85$.

a) Compression-tension, for $\sigma_{c t, \max } \leq 0,026\left|\sigma_{c, \text { max }}\right|$

The following is valid for the case of compression-tension loading, where maximum tensile stress $\sigma_{\mathrm{ct} \text {,max }}$ is lower than or equal to $2,6 \%$ of the absolute maximum compression stress $\sigma_{c, \max }:$ b) Pure tension and tension-compression for $\sigma_{\text {ct,max }}>$ $0,026\left|\sigma_{c, \max }\right|$

The following applies when the maximum tensile stress $\sigma_{\text {ctmax }}$ is greater than $2.6 \%$ of the absolute maximum compression stress $\sigma_{c, \text { max }}$ :

$\log N=12\left(1-S_{c t, \max }\right)$

where $S_{c t \text { max }}$ is the maximum tensile stress level:

$S_{c t, \text { max }}=\frac{\sigma_{c t, \text { max }}}{f_{c t k, \text { min }}}$

$\sigma_{\mathrm{ct}, \text { max }}$ is the maximum tensile stress and $f_{c t k \text {,min }}$ is the minimum characteristic tensile strength of concrete, depending on concrete grade [33].

Case $c$ for pure tension was used in calculation. At that, the corresponding values of $\sigma_{\text {ctmax }}$ are shown in Table 7 and the value of $f_{c t k, \text { min }}$ was adopted as $2.5 \mathrm{MPa}$.

\subsection{AC}

According to $\mathrm{ACl}$ guidelines, the design for fatigue can be facilitated by using the modified Goodman diagram. This diagram is based on the observation that the fatigue strength of plain concrete is essentially the same whether the loading mode is the tension, compression or flexure. The diagram incorporates the influence of the range of load (minimum and maximum values) for one million of load cycles.

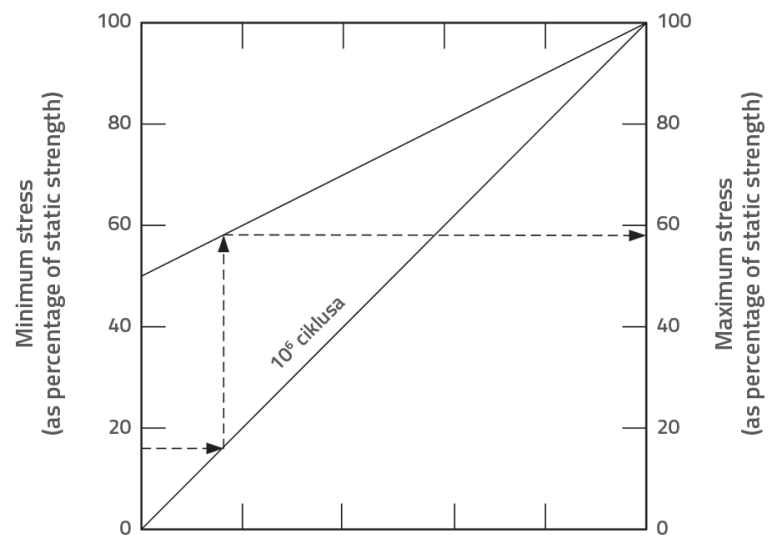

Figure 17. Goodman diagram of concrete under fatigue

The influence of the minimum and maximum stress can be expressed with:

$$
\frac{\sigma_{\max }}{\sigma_{c}}=1-0.0685\left(1-\frac{\sigma_{\min }}{\sigma_{\max }}\right) \log N
$$

$\log N=9\left(1-S_{c, \max }\right)$ 
where $\sigma_{c}$ is the corresponding static strength and $\sigma_{\max }$ and $\sigma_{\min }$ are maximum and minimum stress under fatigue. Eq. (12) applies equally well for the compressive, tensile or flexural loading.

Values $\sigma_{c}$ and $\sigma_{\text {max }}$ used for calculation, are shown in Table 7. The minimum stress $\sigma_{\min }$, as obtained during the test, was 10 $\%$ of $\sigma_{\max }$.

\subsection{JSCE}

The JSCE standard gives the expression that associates the minimum and maximum stress values during cycle loading, with the expected number of cycles $N$, for $N \leq 2 \cdot 10^{6}$ :

$\log N=17 \frac{1-S_{\max }}{1-S_{\min }}$

where $S_{\max }$ and $S_{\min }$ are the maximum and minimum stress levels:

$S_{\max }=\frac{\sigma_{\max }}{\sigma_{c}}$

$S_{\min }=\frac{\sigma_{\min }}{\sigma_{c}}$

As for $\mathrm{ACl}, \sigma_{c}$ is the corresponding static strength, and $\sigma_{\text {max }}$ and $\sigma_{\min }$ are the maximum and minimum stress values during loading.

\section{Comparison and analysis of test results}

\subsection{Comparison of test results and design models}

The comparison between the S-logN curve according to design models and the experimental data is shown in Figure 18. The MC design model differs from other two models because it considers the ratio between the maximum tensile stress $s_{c t \text { max }}$ and the minimum characteristic tensile strength of concrete $f_{c t k, m_{i n}}$ eq. (10). The minimum characteristic tensile strength of concrete was set to $f_{c t k, m i n}=2.5 \mathrm{MPa}$, according to concrete grade C40/50 [33]. The static strength and maximum tensile strength values for plain concrete were lower than the SFRC and HSFRC values, which were almost the same, Table 7. That is why there are two curves in Figure 18: MC1 curve representing plain concrete and $\mathrm{MC2}$ curve representing both 20M20R and 40MOR mixes. JSCE and ACI models consider only the maximum to minimum stress ratio and, because of that, they give a single curve for all mixtures. It can be seen that the results obtained by the MC model are more conservative compared to other two models whose results are quite equable.

All three design models underestimated fatigue life of concrete under fatigue. The exceptions are two PC specimens that were overrated according to $\mathrm{JSCl}$, and one $\mathrm{PC}$ specimen according to
$\mathrm{ACl}$ model. The MC model appeared to be the most conservative one, which was expected because it considers the value of the minimum tensile strength of concrete. ACI and JSCE models consider only the minimum to maximum stress ratio, and their results are quite equable.

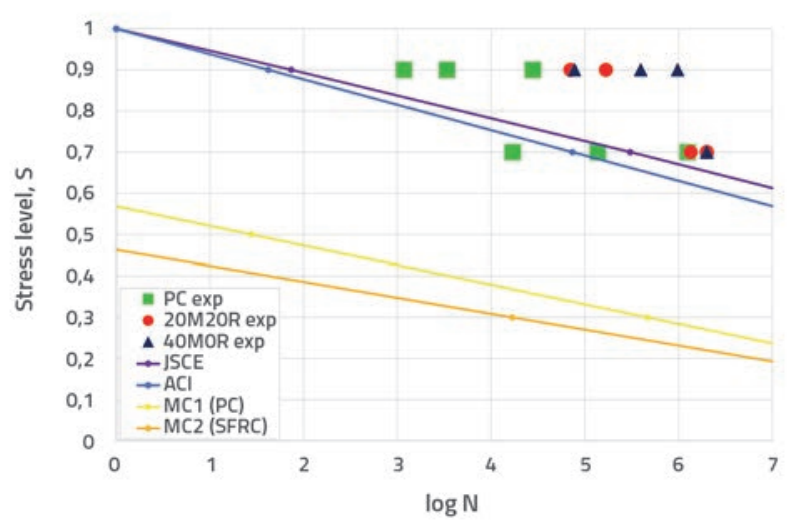

Figure 18. Comparison of S-logN curves according to design models and experimental results

It should be mentioned that all models are developed for the fatigue of plain concrete, and one of the goals of this research was to establish if they could be applied for SFRC.

The MC model gives better prediction for plain concrete (MC1) than for SFRC and HSFRC (MC2), Figure 18. It can be concluded that the MC model is not applicable for SFRC because it considers minimum characteristic tensile strengths of plain concrete, which is much lower than the tensile strength of SFRC. Further analysis shows the MC model adjustment by adapting eq. (11).

\subsection{MC model adjustment}

Besides not being applicable for SFRC predictions, the results obtained by the MC model are the most conservative ones. For these reasons, the MC model adjustment was made as shown below. In the first step of adjustment, the mean tensile strength of concrete $f_{c t m}=3.5 \mathrm{MPa}$ was used instead of the minimum characteristic tensile strength $f_{c t, \text { min }}=2.5 \mathrm{MPa}$ in eq. (11). In the second step, the maximum tensile strength $f_{c t k \text {, } \text { ax }}=4.6 \mathrm{MPa}$ was used instead of $f_{c t, \text { min }}=2.5 \mathrm{MPa}$, Figure 19. Much better prediction of the fatigue behaviour, and better agreement with the other two models ( $\mathrm{ACl}$ and JSCE), was achieved in the second step of adjustment. However, it can be seen in Figure 19 that in this case the model predicts a certain number of cycles even for stress levels higher than $S=1$ (stress exceeding the static strength), which is not possible. That is why the curve was limited by a horizontal line at the stress level $S=1$, although even this does not show a realistic behaviour because the plain concrete has almost no residual strength. For this reason, and considering a relatively small number of tested specimens, it would be premature to conclude that this type of curve can safely predict behaviour 
of plain concrete under fatigue. Having also a certain partial safety factor in mind, the first step adjustment, which uses the mean tensile strength of concrete $f_{c t m}$, can be considered as a contribution to the MC model.

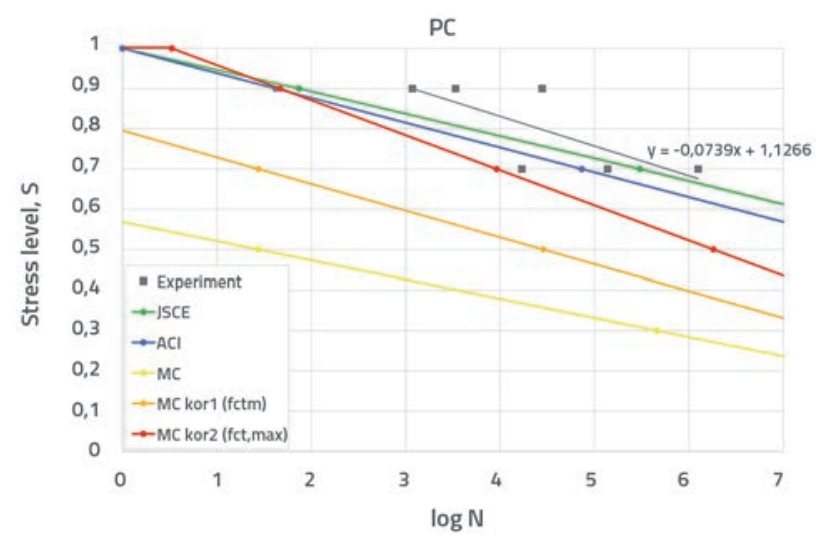

Figure 19. Comparison of S- $\log N$ curve according to MC and versions adjusted by the author

The ratio between residual flexural strengths $f_{R, 3}$ and $f_{R, 1}$ is used for the SFRC classification according to the MC model. These strengths are determined according to [24], Table 6. The residual flexural strength $f_{R, 1}$ is used for the design of ultimate limit state (ULS), while $f_{R, 3}$ is used for designing the serviceability limit state $(S L S)$. For this reason, these values were used for model adjustment in three steps. In the first step, the residual flexural strength $f_{\mathrm{R}, 3}$ was used instead of the minimum tensile strength $f_{c t k \text { min }}$ in eq. (11). The residual flexural strength $f_{\mathrm{R}, 1}$ was used in the second step and the flexural strength at the limit of proportionality $f_{\mathrm{ct}, \mathrm{L}}$ was used in the third step instead of $f_{c t, \text { min. }}$ The results of the adjusted versions of curves for mixtures $20 \mathrm{M} 20 \mathrm{R}$ and 4OMOR are shown in Figure 20 and Figure 21 together with the initial MC curve.

S-N curves for mix 40MOR predict a certain number of cycles at stress level $S=1$, and so they are limited by a horizontal line at this level. For SFRC, it is reasonable to assume that specimens can survive a certain number of cycles at stress level $S=1$ because the post-cracking stage material has a substantial residual strength, so that hardening behaviour is also possible. All three adjustment steps enable improvement of the fatigue model for SFRC. The third step, which uses $f_{\mathrm{ct}, \mathrm{L}^{\prime}}$ describes behaviour of hybrid mix 20M20R most accurately, while the second and the third steps offer similar results for mix 40MOR. The authors suggest the use of flexural strength at the limit of proportionality $f_{\mathrm{ct}, \mathrm{L}}$ in the $\mathrm{MC}$ fatigue design model for plain concrete, which can then be used for fatigue design for SFRC and HSFRC.

\section{Conclusion}

The paper describes fatigue issues during cycle loading and the benefit of using steel fibre reinforced concrete (SFRC)

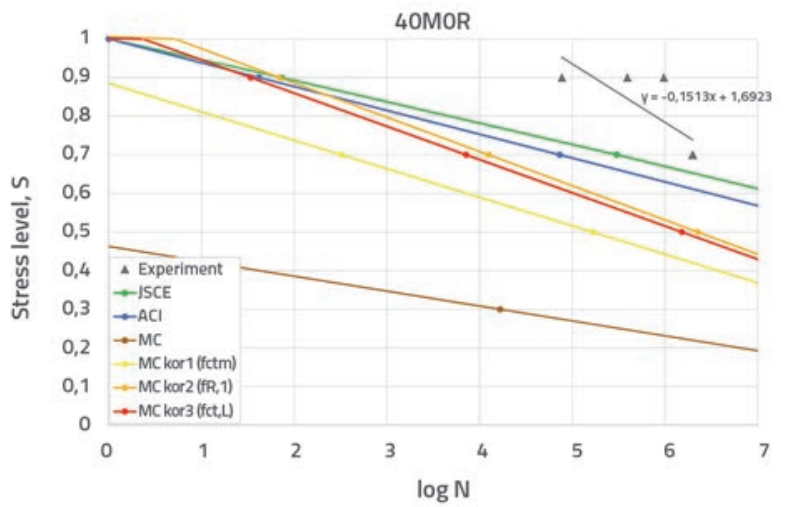

Figure 20. Adjusted versions of MC model for mix 40MOR

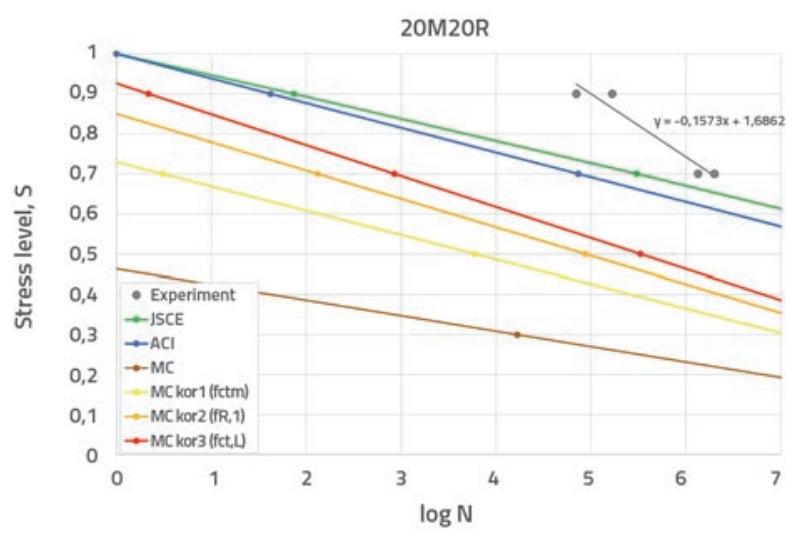

Figure 21. Adjusted versions of MC model for mix 20M20R

in structural elements exposed to this type of loading. The term hybrid steel fibre reinforced concrete (HSFRC) is defined as a product of adding a combination of manufactured and recycled steel fibres from waste tyres to concrete. The aim of this research was to establish whether HSFRC could offer an alternative to the standard SFRC due to fact that recycled fibres are cheaper than manufactured ones and that their usage contributes to solving the environmental problem of waste tyre disposal. A total of 42 concrete elements measuring $150 \mathrm{~mm} x$ $150 \mathrm{~mm} \times 600 \mathrm{~mm}$, and originating from three mix types, were tested. Three fatigue design models were presented: fib Model Code, ACl, and JSCE. An additional objective of this research was to compare fatigue design model predictions with experimental test results, and to assess applicability of such models for fatigue of SFRC.

The SFRC mix, marked 40MOR, showed the best fatigue resistance since all specimens reached two million cycles at stress level $\mathrm{S}=0.7$. The HSFRC mix, marked 20M20R, also demonstrated good fatigue resistance while plain concrete, marked PC, showed the lowest fatigue resistance, as could have been expected. Both fibre mixtures resisted up to 5 times higher displacements compared to PC. Experimental test results indicate that SFRC and HSFRC mixes exhibit a very similar behaviour up to the stress level $S=0.7$. However, the SFRC mix 
demonstrated somewhat better properties than HSFRC just above the stress level $S=0.9$. The scattering of results, which is common in SFRC fatigue testing due to random distribution of fibres, should also be considered. It can be concluded from experiments that the HSFRC mix can be used as an alternative to a standard SFRC mix, and this from engineering, economic and ecological aspects.

The analysis of available fatigue design models shows that the fatigue resistance of concrete is underrated in all models. The only exceptions were two PC specimens that were overrated according to $\mathrm{JSCl}$, and one $\mathrm{PC}$ specimen that was overrated according to the $\mathrm{ACl}$ model. The $\mathrm{MC}$ model appeared to be the most conservative one, which is expected because it considers the minimum tensile strength of concrete. ACI and JSCE models consider only the minimum to maximum stress ratio, and their results are quite equable.

It was concluded that the MC model is not applicable for the fatigue of SFRC, and so the following adjustment is proposed. For plain concrete, the mean flexural strength $f_{c t m}$ should be used in eq. (11) instead of the minimum tensile strength $f_{c t k, m i n}$ and the flexural strength at the limit of proportionality $f_{\mathrm{ct}, \mathrm{L}}$ should be used for SFRC/HSFRC due to its ductility and a relatively small decrease in bearing capacity in the post-cracking zone. A more realistic prediction of fatigue behaviour was achieved after these adjustments. Although the most accurate predictions were obtained using the JSCE model, its estimations still underrated the performance of SFRC and HSFRC. In JSCE and $\mathrm{ACl}$ models, the contribution of fibres in enhancing ductility and tensile strength of concrete should be taken into consideration. Better insight into the possibilities for supplementing design models could be achieved by conducting similar experiments with a larger number of specimens, and at some additional stress levels (from $\mathrm{S}=0.6$ to $\mathrm{S}=0.95$ ).

\section{Acknowledgements}

The authors wish to acknowledge financial support provided in the scope of the $7^{\text {th }}$ Framework Programme of the European Community "Innovative Use of All Tyre Components in Concrete", under the contract number 603722. The authors also gratefully acknowledge contribution of all participants in the above mentioned project, with special thanks to the colleagues from the Faculty of Civil Engineering Zagreb - Department of Engineering Mechanics, and from company Gradmont d.o.o.

\section{REFERENCES}

[1] Krolo J., Šimić D.: Mehanika materijala, Zagreb: Sveučilište u Zagrebu, Građevinski fakultet; 2011.

[2] Lee, M.K., Barr, B.I.G.: An overview of the fatigue behaviour of plain and fibre reinforced concrete, Cem Concr Compos, 26 (2004) 4, pp. 299-305.

[3] Tlemat, H., Pilakoutas, K., Neocleous, K.: Stress-strain characteristic of SFRC using recycled fibres, Mater Struct, 39 (2006), pp. 365-77, https://doi.org/10.1007/s11527-005-90094

[4] Tlemat, H., Pilakoutas, K., Neocleous, K.: Modelling of SFRC using inverse finite element analysis, Mater Struct, 39 (2006) 2, pp. 221-33.

[5] Neocleous, K., Tlemat, H., Pilakoutas, K.: Design issues for concrete reinforced with steel fibers, including fibers recovered from used tires, J Mater Civ Eng, 18 (2006) 5, pp. 677-85.

[6] Achilleos, C., Hadjimitsis, D., Neocleous, K., Pilakoutas, K., Neophytou, P.O., Kallis, S.: Proportioning of Steel Fibre Reinforced Concrete Mixes for Pavement Construction and Their Impact on Environment and Cost, Sustainability, 3 (2011) 7, pp. 965-83, https://doi.org/10.3390/su3070965

[7] Graeff, A.G., Pilakoutas, K., Neocleous, K., Peres, M.V.N.N.: Fatigue resistance and cracking mechanism of concrete pavements reinforced with recycled steel fibres recovered from postconsumer tyres, Eng Struct, 45 (2012), pp. 385-95, https://doi org/10.1016/j.engstruct.2012.06.030
[8] Serdar, M., Baričević, A., Lakušić, S., Bjegović, D.: Betonski proizvodi specijalne namjene od reciklata otpadnih guma, GRADEVINAR, 65 (2013) 9, pp. 793-801.

[9] Serdar, M., Baričević, A., Bjegović, D., Lakušić, S.: Possibilities of use of products from waste tyre recycling in concrete industry, Istraz i Proj za privredu, 12 (2014), pp. 89-93.

[10] Bjegović, D., Baričević, A., Lakušić, S.: Innovative low cost fibrereinforced concrete. Part I: Mechanical and durability properties, In: Alexander MG, Beushausen HD, Dehn F, Moyo P, editors. Concrete Repair, Rehabilitation and Retrofitting III, CRC Press/ Balkema, pp. 199-203, 2012.

[11] Krolo, J., Damjanović, D., Duvnjak, I., Bjegović, D., Lakušić, S., Baričević, A.: Innovative low cost fibre-reinforced concrete. Part II: Fracture toughness and impact strength, In: Alexander MG, Beushausen HD, Dehn F, Moyo P, editors. Concrete Repair, Rehabilitation and Retrofitting III, CRC Press/Balkema, pp. 204209, 2012.

[12] Baričević, A., Bjegović, D., Kovačević, J.: Innovative low cost hybrid fibre reinforced concrete, CPI - Concr Plant Int, 4 (2013), pp. 6470.

[13] Bjegović, D., Baričević, A., Lakušić, S., Damjanović, D., Duvnjak, I.: Positive interaction of industrial and recycled steel fibres in fibre reinforced concrete, J Civ Eng Manag, 19 (2013) 1, pp. S50-60.

[14] Baričević, A.: Doprinos razvoju održivog hibridnog mikroarmiranog betona primjenom produkata reciklaže otpadnih guma, Disertacija. Građevinski fakultet, Zagreb; 2014. 
[15] Bartolac, M.: Svojstva predgotovljenih konstruktivnih elemenata s djelomičnom zamjenom armature recikliranim čeličnim vlaknima, Disertacija, Građevinski fakultet, Zagreb, 2015.

[16] Projekt Anagennisi, D1.7 Characterised materials of sufficient quantities, FP7 Project: Innovative Reuse of all Tyre Components in Concrete, 2014.

[17] Twincon.: Technical Data Sheet, Steel fibres RTSF -High strength reused steel fibre

[18] HZN: HRN EN 12350-6:2000 Ispitivanje svježega betona - 6. dio: Gustoća

[19] HZN: HRN EN 12350-7:2009 Ispitivanje svježega betona - 7. dio: Sadržaj pora - Tlačne metode

[20] HZN: HRN EN 12350-2:2009 Ispitivanje svježega betona - 2. dio: Ispitivanje slijeganjem

[21] HZN: HRN EN 12390-3:2012. Ispitivanje očvrsloga betona - 3. dio: Tlačna čvrstoća ispitnih uzoraka

[22] HZN: HRN EN 12390-6:2010. Ispitivanje očvrsloga betona - 6 . dio: Vlačna čvrstoća cijepanjem

[23] HZN: HRN EN 12390-13:2013. Ispitivanje očvrsloga betona -13. dio: Određivanje sekantnog modula elastičnosti pri tlaku

[24] HZN: HRN EN 14651:2008 - Ispitna metoda za beton ojačan metalnim vlaknima - Mjerenje savojne čvrstoće

[25] ACl Committee 544.: Measurement of Properties of Fiber Reinforced Concrete, 89 (1999).

[26] Graeff, A.G.: Long-term performance of recycled steel fibre reinforced concrete for pavement aplication, $\mathrm{PhD}$ thesis. University of Sheffield; 2011.

[27] Sahin, Y., Köksal, F.: The influences of matrix and steel fibre tensile strengths on the fracture energy of high-strength concrete, Constr Build Mater, pp. 1801-1806. 2011.
[28] Naaman, A.E.: Fibre reinforced concrete: State of Progress at the edge of the new millennium, In: Proceedinngs of the ACI-KC $2^{\text {nd }}$ International Conference Design and Sustainability of Stuctural Concrete in the Middle East with Emphasis on High-Rise Buildings, Kuwait; 207AD.

[29] Shah, A.A., Ribakov Y.: Recent trends in steel fibered highstrength concrete, Mater Des, pp. 4122-4151, 2011, https://doi. org/10.1016/j.matdes.2011.03.030

[30] Angelakopoulos, H., Neocleous, K., Pilakoutas, K.: Uniaxial compressive behaviour of steel fibre reinforced roller compacted concrete, In: 6th International Conference Fibre Concrete 2011, Prague, Czech Republic; 2011

[31] Baričević, A., Bjegović, D., Skazlić, M.: Hybrid Fiber - Reinforced Concrete with Unsorted Recycled-Tire Steel Fibres, J Mater Civ Eng, 2016 (2009)

[32] Neocleous, K., Angelakopoulos, H., Pilakoutas, K., Guadagnini, M.: Fibre- reinforced roller-compacted concrete transport pavements, Proceeding ICE - Transp, 164 (2011) 2, pp. 97-109.

[33] Federation internationale du beton: Model Code for Concrete Structures 2010, 2013

[34] Chang, D.: Flexural fracture and fatigue behavior of steel-fiberreinforced concrete structures, 156 (1995), pp. 201-207.

[35] ACl Committee 2015.: Considerations for Design of Concrete Structures Subjected to Fatigue Loading Reported by ACl Committee 215, pp. 74, 1997.

[36] Shah, N.M., Surendra, P.: American concrete institute considerations for fatigue, 1982.

[37] Japan Society of Civil Engineers.: Standard Specifications for Concrete Structures, 2007, Design, 2010. 